\title{
Biofilm Accumulation and Structure in the Flow Path of Drip EMitTERs Using ReClaimed WASTEWATER
}

\author{
D. Yan, P. Yang, M. Rowan, S. Ren, D. Pitts
}

\begin{abstract}
Biofouling has been identified as a major contributor to emitter clogging in drip irrigation systems that distribute reclaimed wastewater. Two types of drip emitters were evaluated for use with reclaimed wastewater. Microbial biofilm accumulations, including proteins, polysaccharides, and phospholipid fatty acids (PLFAs), were tested to determine the biofilm development and diversity in the emitter flow path. The microbial biofilm structure was analyzed using scanning electron microscopy (SEM). The results showed rapid growth of the biofilm and accumulated sediments that led to eventual reduction of emitter discharge, and the biofilm played an inducing role in the clogging process. Biomass growth in the emitter flow path fluctuated as biomass was scoured off the surface areas. The scoured sediment tended to accumulate and clog the outlets or other emitter parts. Microphotographs revealed microparticles in the biofilm matrix coupling with extracellular polymeric substance (EPS) and showed the biofilm attachment process that would initiate clogging in the emitter flow path. The particle size of the clogging sediment can be very small, and filtration alone was not an effective treatment to control emitter clogging. This study provides some suggestions for control of clogging, and it may provide a framework for future investigations into the role of biofilms in the clogging of drip emitters that distribute reclaimed wastewater.
\end{abstract}

Keywords. Biofilm, Extracellular polymeric substance, Microirrigation, Phospholipid fatty acid, Reclaimed wastewater.

A s the demand for fresh water increases, wastewater effluent is receiving increasing attention as an alternate irrigation water source. The use of wastewater requires irrigation methods that minimize health and environmental risks. Drip irrigation can be an effective method for wastewater utilization since it includes several advantages over other irrigation methods: (1) human contact and associated health risks are minimized, (2) no aerosols are generated, (3) no wastewater contacts plant foliage, (4) water logging, runoff, and deep percolation can be minimized, and (5) there is less potential pollution hazard due to minimal use of herbicides. Oron et al. (1999) reported that subsurface microirrigation reduced the risk of pollution associated with wastewater to a minimum since the soil acts as a living filter, cleaning the water.

Due to a growing utilization of drip irrigation for wastewater applications, emitter anti-clogging capability is critical. Wastewater intensifies the potential for microorganisms to develop and produce a biofilm layer on the inner surfaces of a micro-irrigation system. Biofilm formation can result in de-

Submitted for review in September 2009 as manuscript number SW 8206; approved for publication by the Soil \& Water Division of ASABE in April 2010.

The authors are Dazhuang Yan, Doctoral Student, and Peiling Yang, Professor, College of Water Conservancy and Civil Engineering, China Agricultural University, Beijing, China; Mike Rowan, Lecturer, Department of Food, Agricultural and Biological Engineering, The Ohio State University, Columbus, Ohio; Shumei Ren, Professor, College of Water Conservancy and Civil Engineering, China Agricultural University, Beijing, China; and Donald Pitts, Senior Engineer, USDA Natural Resources Conservation Service, Urbana-Champaign, Illinois. Corresponding author: Peiling Yang, College of Water Conservancy and Civil Engineering, China Agricultural University, P.O. Box 57, No 17, Tsinghua East Road, Beijing, China; phone: 86-010-6273-6911; fax: 86-010-6273-6911; e-mail: yang-pl@163.com. creased or uneven discharge and emitter clogging. Some bacterial species can reduce the iron, manganese, and sulfur minerals dissolved in water and may precipitate those substances in the flow path of emitters (James, 1988; Pitts et al., 1990; Şahin et al., 2005). In addition, there are common microbial sources of emitter clogging, including protozoa and fungi, that form mucous membranes, filamentous slimes, and various adhesive excretions. These biofilms can agglomerate fine mineral and organic particles, producing large flocs that clog the emitters (Adin and Sacks, 1991; Taylor et al., 1995). The growth and development of the aerobic slime-forming bacteria may also cause emitter clogging problems (McElhoe and Hilton, 1974; Ford, 1979).

Several groups of investigators have suggested examining the biofilm sediments involved in emitter clogging to determine the correlative relationships between clogging and biofilm biomass (Adin and Sacks, 1991; Rowan, 2004; Cararo et al., 2006). Iron and sulfur bacteria have been discovered in emitter-clogging sediments (Cararo et al., 2006), and these sediments may mainly result from the respiration of some correlative bacteria. Rowan (2004) analyzed dripper biofilm biomass through ATP (adenosine triphosphate) measurements. The results showed that the ATP (biomass) measurements did not correlate with flow rate reduction. He concluded that wastewater quality was a determining factor in the biofilm development process and that secondary treatment of influent wastewater reduced the incidence of emitter clogging.

The actual structure of a biofilm in the emitter flow path is complex. Commonly, the bacteria in a biofilm aggregate at different horizontal and vertical sites, with the highest concentration of cells occurring at the base or at the top, resulting in a mushroom-like shape (Rowan, 2004). Another major part of the biofilm structure is the protective mass of extracellular polymeric substance (EPS), an adhesive containing 
both organic and inorganic components accumulated from the surrounding environment (Characklis and Marshall, 1990). A diverse group of polymers can be highly attached to the cell surfaces or released as extracellular slime in the surroundings of the cells (Knoshaug et al., 2000). In the early stages of biofilm formation, a polysaccharide matrix provides a structure for the microorganisms to reside. The EPS of the biofilm captures and incorporates suspended particles and helps to build the three-dimensional matrix structure, and thus poses a potential for clogging of the emitter flow path.

This article describes the biomass accumulation process, the structural characteristics present at different phases of biofilm development, and the relationship between biomass accumulation and clogging in a drip irrigation system receiving reclaimed wastewater. The predominant bacteria (represented by phospholipids fatty acids) that clogged emitters with biological slime deposits are also identified. This information may provide insight into the processes of biofilm formation and emitter clogging and lead to methods to reduce clogging and prevent premature failure of drip irrigation systems that use wastewater effluent.

\section{Materials AND Methods \\ DRIP IRRIGATION SYSTEM}

The emitter clogging tests were conducted from May to July 2008 in the experimental hall of China Agricultural University in Beijing, China. The two emitter types tested (figs. 1 and 2 , table 1) were selected based on regional availability and are representative of the current technology in China. The experimental setup consisted of 60 emitters of each type placed inline $0.3 \mathrm{~m}$ apart with three tubes of each kind of emitter. The system included a 150 micron disk filter, a 100 micron disk filter, and two pressure regulator valves (fig. 3). Reclaimed wastewater was provided by the Gaobeidian Wastewater Treatment Plant in Beijing, China. The physical, chemical, and microbiological characteristics of the reclaimed wastewater are given in table 2 . Reclaimed wastewater was delivered to the drip tubing from a $50 \mathrm{~m}^{3}$ dosing tank. To evaluate emitter performance, discharge measurements were taken at the beginning of the experiment and then taken periodically throughout $220 \mathrm{~h}$ of irrigation (four days of system operation at $6 \mathrm{~h}$ per day and one day off). The operating pressure for all treatments was maintained at 100 $\mathrm{kPa}$, and water temperature was monitored.

\section{Biofilm Collection}

Biofilms were collected from the emitter flow path after 48 h, 72 h, 96 h, 120 h, 144 h, 168 h, 192 h, and 216 h of inter-

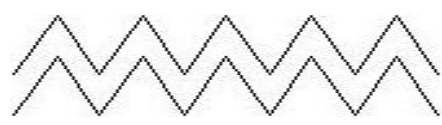

(a)

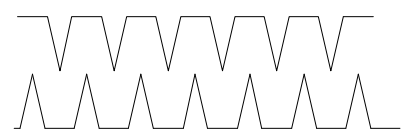

(b)

Figure 1. Flow path structures of emitters.

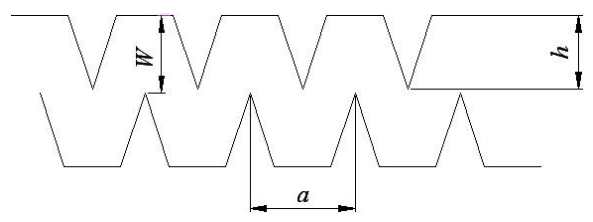

Figure 2. Parameter notation.

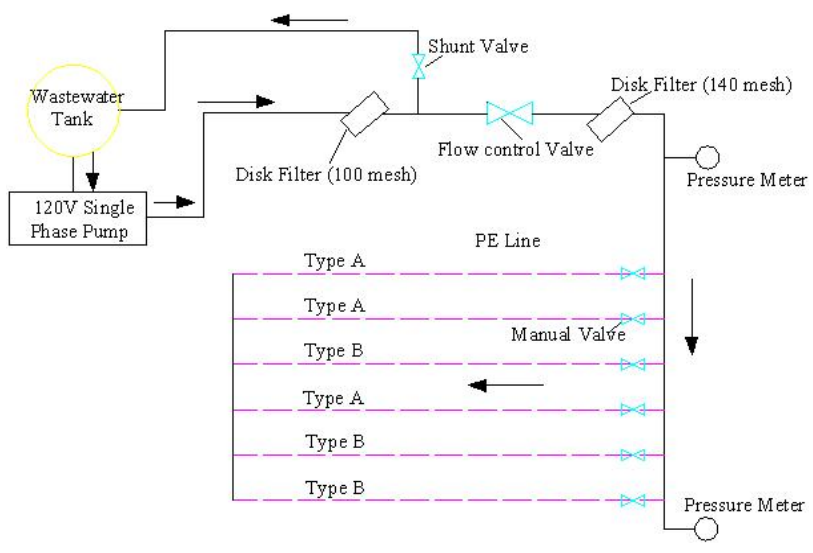

Figure 3. Experimental layout of drip irrigation system with reclaimed wastewater application.

mittent irrigation. Three random samples were collected from each lateral line, and the lines were reconnected using fittings. In the laboratory, biofilms were detached from emitter flow paths by cutting open the emitters, placing them in $100 \mathrm{~mL}$ of sterile water, adding $5 \mathrm{~g}$ sterile glass beads, and shaking for $2 \mathrm{~h}$. Keinänen et al. (2004) demonstrated that this technique removes $98 \%$ of biofilm cells.

\section{Analysis Methods}

Emitter discharge rates were determined by collecting individual flows from each emitter over a period of $10 \mathrm{~min}$ and measuring the flow amount using a graduated cylinder. An

Table 1. Characteristic of the dripper emitter.

\begin{tabular}{ccccccccc}
\hline & $\begin{array}{c}\text { Pipe } \\
\text { Diameter, } \\
\phi(\mathrm{mm})\end{array}$ & $\begin{array}{c}\text { Width of } \\
\text { Flow Path, } \\
W(\mathrm{~mm})\end{array}$ & $\begin{array}{c}\text { Depth of } \\
\text { Flow Path, } \\
D(\mathrm{~mm})\end{array}$ & $\begin{array}{c}\text { Length of } \\
\text { Flow Path, } \\
L(\mathrm{~mm})\end{array}$ & $\begin{array}{c}\text { Dentation } \\
\text { Space, } \\
a(\mathrm{~mm})\end{array}$ & $\begin{array}{c}\text { Dentation } \\
\text { Height, } \\
h(\mathrm{~mm})\end{array}$ & $\begin{array}{c}\text { Nominal } \\
\text { Discharge, } \\
q\left(\mathrm{~L} \mathrm{~h}^{-1}\right)\end{array}$ & $\begin{array}{c}\text { Emitter } \\
\text { Exponent }^{2}\end{array}$ \\
\hline $\mathrm{A}$ & 16 & 1.02 & 0.94 & 50 & 1.01 & 1.93 & 2.75 & 0.54 \\
$\mathrm{~B}$ & 16 & 1.13 & 0.89 & 360 & 1.60 & 1.71 & 1.87 & 0.53 \\
\hline
\end{tabular}

Table 2. Characteristics of reclaimed wastewater in the dosing tank.

\begin{tabular}{ccccccccr}
\hline $\begin{array}{c}\mathrm{Fe} \\
\left(\mathrm{mg} \mathrm{L}^{-1}\right)\end{array}$ & $\mathrm{pH}$ & $\begin{array}{c}\mathrm{Mn}^{2+} \\
\left(\mathrm{mg} \mathrm{L}^{-1}\right)\end{array}$ & $\begin{array}{c}\text { Hardness } \\
\left(\mathrm{mg} \mathrm{L}^{-1}\right)\end{array}$ & $\begin{array}{c}\mathrm{COD} \\
\left(\mathrm{mg} \mathrm{L}^{-1}\right)\end{array}$ & $\begin{array}{c}\mathrm{BOD}_{5} \\
\left(\mathrm{mg} \mathrm{L}^{-1}\right)\end{array}$ & $\begin{array}{c}\text { TSS } \\
\left(\mathrm{mg} \mathrm{L}^{-1}\right)\end{array}$ & $\begin{array}{c}\text { TDS } \\
\left(\mathrm{mg} \mathrm{L}^{-1}\right)\end{array}$ & $\begin{array}{c}E . \text { coli } \\
\left(100 \mathrm{~mL}^{2}\right.\end{array}$ \\
\hline 0.036 & 7.84 & 0.048 & 595 & 62.7 & 32.8 & 45.9 & 645 & $\geq 2400$ \\
\hline
\end{tabular}


emitter was considered to be clogged when the emitter discharge was less than $75 \%$ of nominal discharge.

The emitter biofilm biomass and microbial community were analyzed for phospholipids fatty acids (PLFAs). This method provides an unbiased view of the complex microbial communities and viable biomass found in environmental samples such as soils (Ratcliff et al., 2006), sediments (Ringelberg et al., 1997), and drinking water system biofilms (Smith et al., 2000; Keinänen et al., 2004). This method is based on the assumption that phospholipids make up a relatively constant proportion of the cell biomass and that fatty acid variation among taxonomic groups provides markers that can be used to interpret community-level profiles (Zhang et al., 2008). PLFAs were extracted using a modified procedure described by Pennanen et al. (1999). Biofilms collected from the surface of the emitter flow path were transferred to a glass tube. Lipids were extracted by a one-phase chloroform, methanol, and $0.15 \mathrm{M}$ citrate buffer extractant (1:2:0.8, v:v:v) by shaking $4 \mathrm{~h}$ at $20^{\circ} \mathrm{C}$ (White et al., 1979). The lipid extract was applied in chloroform to the top of the column. Neutral lipids were eluted with $5 \mathrm{~mL}$ of chloroform, glycolipids with $10 \mathrm{~mL}$ of acetone, and phospholipids with $10 \mathrm{~mL}$ of methanol (Keinänen et al., 2004; Xue et al., 2005). The methyl ester of nonadecanoic acid (19:0) was added as an internal standard immediately before the separated phospholipids fatty acid was transesterified into fatty acid methyl esters using a mild alkaline methanolysis reaction. Fatty acid methyl esters (FAMEs) were analyzed using a GC-MS system (HP 6890, Hewlett Packard, Palo Alto, Cal.) equipped with an HP-5 capillary column $(60 \mathrm{~m} \times 0.32 \mathrm{~mm})$. The total quantity was determined using methyl esters of nonadecanoic acid as an internal standard. PLFAs were named by standard nomenclature (Frostegard et al., 1993). Fatty acids with C14 to C18 carbon chain lengths were used to analyze microbial community structure. PLFA data were reported as means together with standard error of the mean (SE). Analysis of PLFA profiles of the two emitter types was carried out in triplicate.

Extraction of biofilm EPS was carried out according to the methods of Frølund et al. (1996). The biofilm suspension was centrifuged at $2000 \times g$ for $15 \mathrm{~min}$ at $4{ }^{\circ} \mathrm{C}$. The biofilm sediment was resuspended using a buffer consisting of $2 \mathrm{mM}$ $\mathrm{Na}_{3} \mathrm{PO}_{4}, 9 \mathrm{mM} \mathrm{NaCI}, 4 \mathrm{mM} \mathrm{NaH} \mathrm{PO}_{4}$, and $1 \mathrm{mM}$ KCI at $\mathrm{pH}$ 7.0. The total EPS was extracted by heating at $80^{\circ} \mathrm{C}$ for $1 \mathrm{~h}$ and harvested by centrifugation for $15 \mathrm{~min}$ at $12000 \times \mathrm{g}$ and $4^{\circ} \mathrm{C}$. Total polysaccharides were determined by the phenolvitriol method (Leonardos and Lucas, 2000). Glucose was used as a standard. The Lowry method was employed for total protein determination in the EPS. Bovine serum albumin (BSA) was used as a standard.

The biofilm EPS, including proteins and polysaccharides, was transformed to milligram per unit volume $\left(\mathrm{mg} \mathrm{mm}^{-1}\right)$. Fatty acids were transformed to mole per unit volume $(\mathrm{nmol} \mathrm{mm}-1)$.

Emitter flow paths covered with biofilms were observed using ESEM (environmental scanning electron microscopy). Prior to ESEM observations, biofilm samples were fixed with glutardialdehyde ( $2.5 \%$ in $50 \mathrm{mM}$ sodium cacodilate). Upon fixation, samples were incubated in the dark in an osmium tetraoxide solution ( $1 \%$ in $50 \mathrm{mM}$ sodium cacodiolite), dehydrated using an ethanol/water gradient (25\% to $100 \%)$, and finally critical point dried. The samples were sputter-coated with gold $(\mathrm{Au})$ and examined with an environmental scan- ning electron microscope (Quanta 200, FEI, Hillsboro, Ore.) at $10 \mathrm{kV}$. ESEM observations were documented through the acquisition of at least five representative microphotographs in three fields of each position on the flow path.

\section{Results AND Discussion \\ WATER QUALITY}

Relative biomass in the emitters was determined in a drip irrigation system receiving reclaimed wastewater. The water temperature, measured at the middle of each drip line, ranged from $20^{\circ} \mathrm{C}$ (May) to $27^{\circ} \mathrm{C}$ (July). While it has been reported that $\mathrm{pH}$ may not have a direct impact on clogging, it can accelerate the chemical reactions or biological growth involved in clogging (Nakayama and Bucks, 1991; Dehghanisanij et al., 2005). A pH range of $7.0<\mathrm{pH}<8.0$ (as recorded for the samples in this study) would produce a medium clogging potential (Nakayama and Bucks, 1991) since the relatively high hardness, and this $\mathrm{pH}$, would indicate some potential for calcium and magnesium precipitation. The low concentrations of $\mathrm{Fe}$ and $\mathrm{Mn}$ in the irrigation water reflect a low risk of clogging of the emitter flow paths by these metals. The E. coli concentrations were also measured. However, predicting the bioclogging potential of the wastewater based on $E$. coli is problematic since no standard correlation to clogging has been established.

\section{INFLUENCE OF BIOMASS ACCUMULATION ON EMITTER Clogging Degree}

Each point on the emitter discharge graph (fig. 4) represents the mean discharge of 20 emitters along each lateral line over a five-day period (10 min observation). The two emitter types showed similar changes in discharge rate over the course of the experiment. The discharge of the emitters displayed a small fluctuation at the first operation and then decreased quickly from the middle of June (about $120 \mathrm{~h}$ ) to the end of the test in July. The abrupt drop in discharge may have been caused by the temperature increase, which could result in an increased rate of plankton growth or calcium and magnesium precipitation. The clogging in the emitters is slow in the early phase of irrigation, but the discharge decreased sharply once a slight clog formed in the emitters. Similar results were reported by $\mathrm{Li}$ et al. (2009).

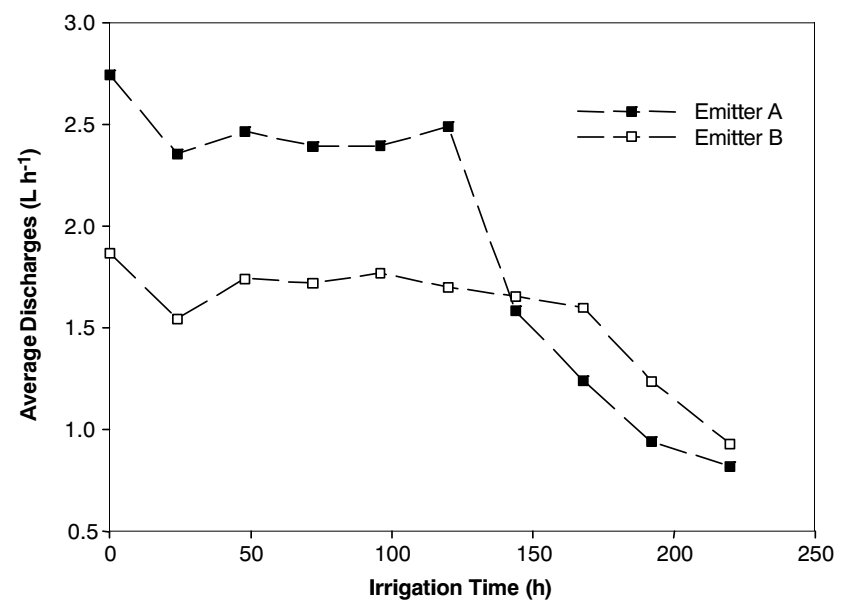

Figure 4. Emitter average discharge variation over irrigation time compared with initial discharge. 


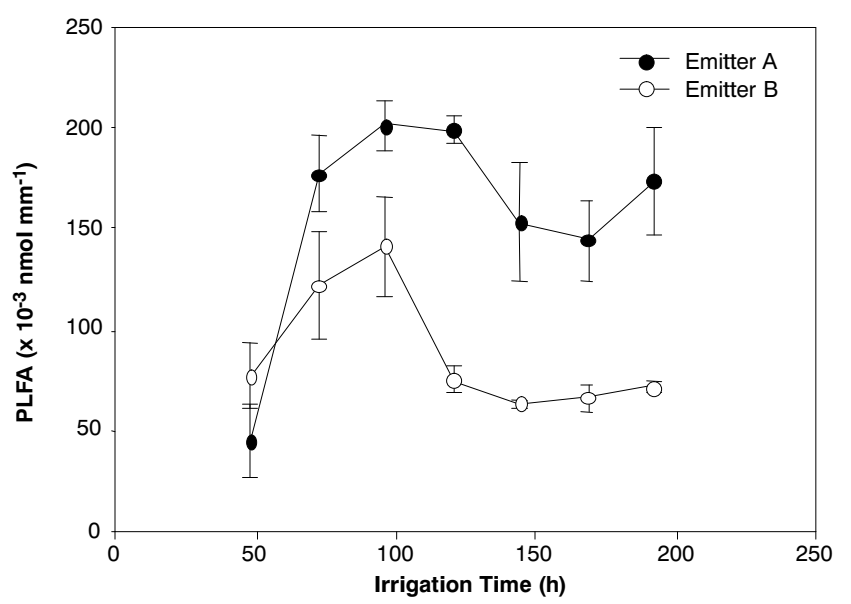

Figure 5. Total PLFAs in emitter flow path with reclaimed wastewater.



Figure 6. Total polysaccharides in emitter flow path with reclaimed wastewater.

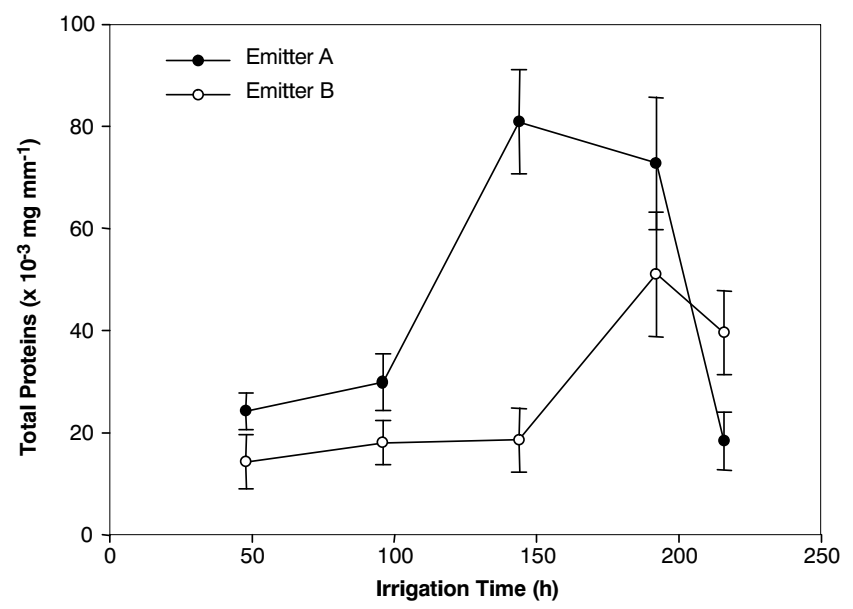

Figure 7. Total proteins in emitter flow path with reclaimed wastewater.

The total amount of PLFAs was used to indicate microbial biomass in the emitter biofilms. Figure 5 shows the changes in the emitter biomass accumulation during system operation. The highest PLFA concentrations (emitter A: $201.46 \times$ $10^{-3} \mathrm{nmol} \mathrm{mm}^{-1}$; emitter B: $\left.141.25 \times 10^{-3} \mathrm{nmol} \mathrm{mm}^{-1}\right)$ in the flow paths occurred after approximately 96 to $144 \mathrm{~h}$ of operation, after which the PLFAs dropped rapidly during the next $48 \mathrm{~h}$ and then recovered to a certain extent through the end of dosing. This fluctuation of biomass accumulation supports the hypothesis for biofilm formation in the emitter flow path described by Taylor et al. (1995): as the biofilm thickness increases, the biofilm organisms become less able to obtain nutrients. Cell death weakens the attachment of the biofilm. Hydraulic shear forces during irrigation lead to "sloughing off" of patches of biofilm, which then provide space for the attachment of new organisms from the wastewater influent.

Previous research has reported the impact of the microbial community on emitter clogging. For example, some aerobic bacteria (nonfilamentous aerobic Pesudomonas spp.) are able to oxidize and precipitate soluble ferrous iron (Ford, 1979; McElhoe and Hilton, 1974). PLFA analysis showed a general classification of microbes in the emitter biofilm. The PLFAs 14:0, 16:0, 16:1w7c, 17:0, 18:2 $\omega$, and 18:0 were the main bacterial PLFAs in this experiment. Fungi and algae $(18: 2 \omega)$ are also important factors in emitter biological clogging, and substantial reduction in discharge is attributed to the accumulation of algae population (Dehghanisanij et al., 2005). The PLFA profiles indicated that about $20 \%$ to $26 \%$ of the total PLFA was fungal $(18: 2 \omega)$ in this experiment.

The extracellular polymeric substance (EPS) was characterized in terms of total polysaccharides and proteins. The ratio of protein to polysaccharide ranged from 0.21 to 1.90 , but the total polysaccharide was more dominant in the EPS than the total protein for the mature biofilm (after $100 \mathrm{~h}$ of operation, figs. 6 and 7). Overall, polysaccharides and proteins both increased and then similarly declined with the accumulated dosing time. Both total protein and total polysaccharide measurements in emitter type A were generally greater than in emitter type $\mathrm{B}$, except for one polysaccharide point $(48 \mathrm{~h})$ and one protein point $(212 \mathrm{~h})$.

After the initial $96 \mathrm{~h}$ period, total polysaccharides increased sharply, reaching $0.22 \mathrm{mg} \mathrm{mm}^{-1}$ (emitter A) and $0.08 \mathrm{mg} \mathrm{mm}^{-1}$ (emitter B) at about $144 \mathrm{~h}^{-1}$ of operation, and then decreased continuously to the end of dosing. This pattern is very similar to that of the total biomass (PLFAs). A previous study indicated that biofilm cohesiveness was strongly correlated with biofilm polysaccharide content, which increased with the thickness but not with the age of the biofilm (Ahimou et al., 2007). From figure 4, the total polysaccharide of emitter $\mathrm{A}$ is much more than that of emitter $\mathrm{B}$, especially in the period from $96 \mathrm{~h}$ to $144 \mathrm{~h}$. This suggests that the design of emitter A may result in less flow shearing force, allowing for more biofilm development and thus resulting in emitter A clogging more rapidly. Chlorine injection is a common irrigation water treatment method to control biological growth and limit emitter clogging potential. Based on these results, chlorine might best be injected into the drip system between $48 \mathrm{~h}$ and $96 \mathrm{~h}$ to minimize biomass, since PLFAs and polysaccharide grow fastest during this period.

The total protein profiles are in shown in figure 7. After approximately $144 \mathrm{~h}$ of operation, total protein reached its maximum value and then decreased through the end of the experiment. The change in protein lagged behind the biomass variation. The protein levels remained higher even when the PLFAs were reduced.

Based on emitter discharge data (fig. 4), the anti-clogging performance of emitter B was better than that of emitter A. Emitter A clogged after $120 \mathrm{~h}$ (average discharge $<75 \%$ 
nominal discharge), while total biomass and polysaccharides remained at high levels. Emitter B remained unclogged (average discharge $>75 \%$ nominal discharge) for at least $168 \mathrm{~h}$ of dosing, while biomass accumulated but polysaccharides decreased during this period.

In the first $96 \mathrm{~h}$ of the experiment, total biomass (PLFAs, fig. 5) and total polysaccharides (fig. 6) increased sharply, and the discharges of both emitter types (A and B) decreased by about $13 \%$ and $7 \%$, respectively. This early phase can be regarded as the period of biofilm formation. It began with the deposition of amorphous bacterial slimes, to which other particles adhered. With biomass accumulation, clogging may be initiated; particles can be attached in the slimy biofilm and reduce the emitter flow path's effective diameter. In the next $72 \mathrm{~h}$, the biomass of emitter A kept decreasing, and the discharge decreased sharply after increasing a little. This result may have been due to a lack of nutrients causing death of deep biofilm cells, which resulted in lower PLFAs while the sediment maintained a great thickness. The hydraulic shearing force may have weakened the attachment of the biofilm, and the scoured biofilm debris was then transported downstream to clog the emitters, especially the outlets. For emitter B in this phase, the biomass accumulation trend was rapidly downward, but the discharge reductions were relatively moderate. The reason for this phenomenon might be the low flow velocity in emitter $\mathrm{B}$ because of the bigger flow path area. This observation differs from previous results, which suggested that a short-path emitter would be more suitable for wastewater drip irrigation (Cararo et al., 2006). This result may indicate that the anti-clogging performance of emitters is complicated, and it may be difficult to explain and evaluate it using only few structural factors.
The emitter's structure and design has an important effect on biofilm accumulation on the surface of the flow path (Yan et al., 2009). The emitter flow path is small (about $1.0 \mathrm{~mm}^{2}$ ), and the boundary conditions affect the flow process. However; these results indicate that emitter A, which had a shorter flow path and smaller surface area, accumulated more biomass and EPS. Emitter A's dentate structure could produce effective jet deflection at the tips and dissipate the energy significantly (Yan et al., 2007), but this narrow structure (dentation space is small) might also cause insufficient reverse flow to flush the corners, thus allowing more micro-organism growth.

\section{Biofilm Structure in Emitter Flow Path}

Biofilms have been defined as "matrix-enclosed bacterial populations adhered to each other and/or to surfaces or interfaces" (Costerton et al., 1995). Kumar and Anand (1998) defined a biofilm as a metabolically active matrix of cells and extracellular compounds. The biofilm structure in the emitter flow paths was investigated by ESEM. ESEM microphotographs representative of the multiple fields observed on the biofilm-covered path surface of emitter B after $96 \mathrm{~h}$, $144 \mathrm{~h}$, and $216 \mathrm{~h}$ are shown in figures 8, 9, and 10, respectively. The sediment buildup began with the formation of biological films and slimes, to which particles adhered. The weight contents of carbon, oxygen, phosphorus, calcium, and magnesium of the final clogging sediments were very similar to typical values in biological organism cells, according to the energy spectroscopic analysis results, which might also indicate that the biological organism is the main component in the clogging materials. At $96 \mathrm{~h}$, bacteria (marked by arrows in fig. 8) have colonized a significant portion of the surface, but few particles have adhered to the biofilm. With the accumulation of dosing time, surface



Figure 8. SEM micrographs of biofilms in emitter flow path after $96 \mathrm{~h}$ of irrigation with reclaimed wastewater $(5000 \times)$. 


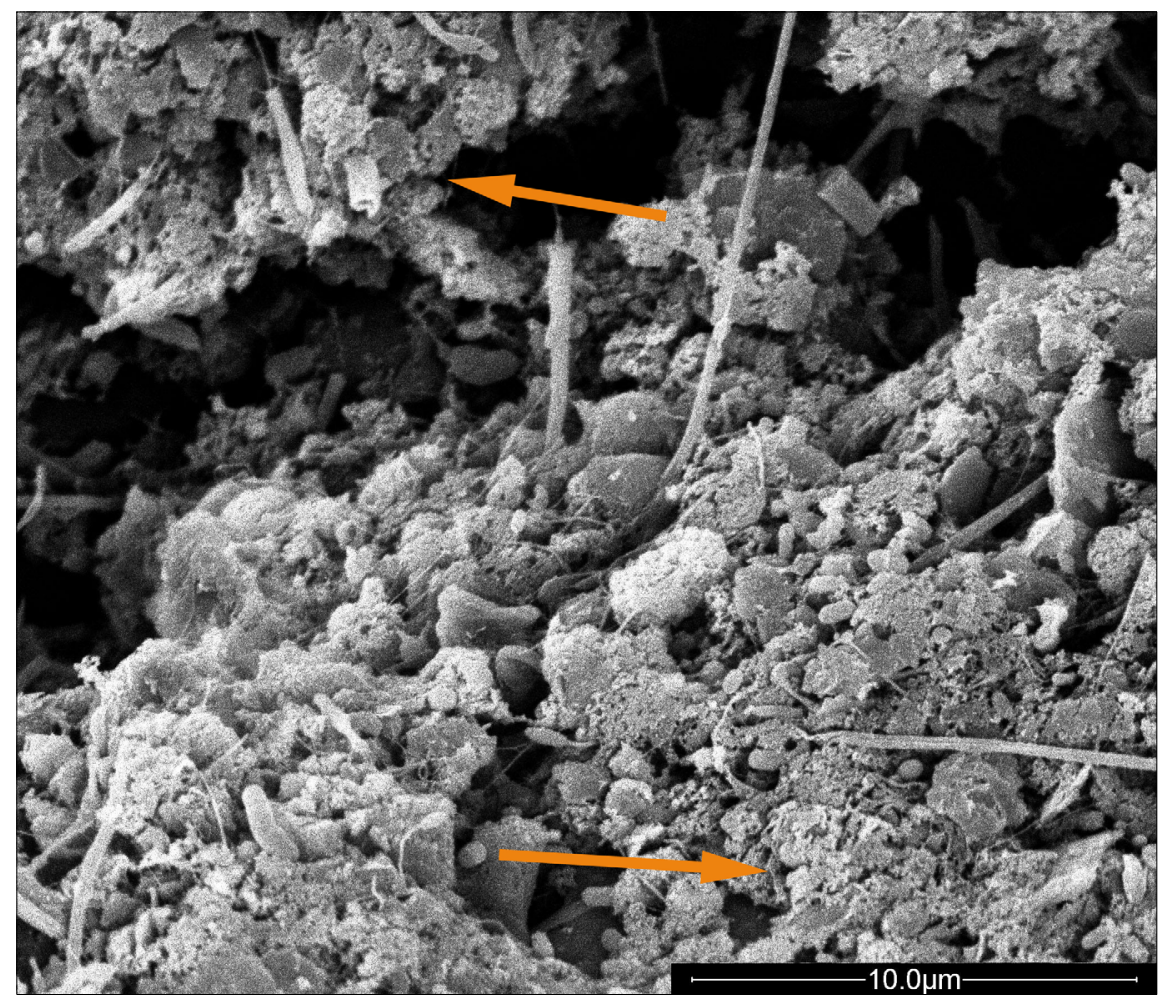

Figure 9. SEM micrographs of biofilms in emitter flow path after $144 \mathrm{~h}$ of irrigation with reclaimed wastewater $(5000 \times)$.



Figure 10. SEM micrographs of biofilms in emitter flow path after $216 \mathrm{~h}$ of irrigation with reclaimed wastewater $(5000 \times)$.

attachment appears to be more complete, and the biofilm surface appears both coarse and slimy. This could be attributed to the mixture of the bacterial layer and embedded particles. It is obvious that large amounts of bacteria, EPS, and microparticles (marked by arrows in fig. 9) are present in the biofilm and form the flocculent structure. Mature biofilms were observed to have a greater amount of bacterial cells within the biofilm matrix as dense aggregates of the microbial community held together. These cellular aggregates were surrounded by void areas, which may 
represent water channels that are used by biofilm cells for nutrient circulation and to facilitate waste removal (Donlan and Costerton, 2002). The microphotographs give insight into the clogging process in the flow path: the microbial cells first adhered to the surface. The cells then began to cluster where previously only small numbers of single cells were visible at locations along the flow path (fig. 8). Finally, the bacteria-coupling EPS build microcolonies with a complex three-dimensional architecture (rectangle in fig. 10). Microparticles were also found trapped in the matrix of the biofilm and formed flocculent structures (marked by arrows in fig. 9), which increased the volume of the sediment until they blocked the emitter flow path. The biofilm thus played an inducing role in the clogging process.

According to the ESEM data, the particles trapped in the biofilm are much smaller than the effective filter size $(0.1 \mathrm{~mm})$. This indicated that, while proper filtration was effective to control large sediment particles $(>0.1 \mathrm{~mm})$ in the flow path, these microparticles passed through the filter and were trapped by the biofilm, thus increasing agglomerate thickness. The filamentous bacteria and EPS appeared to play an important "bridging" function between the flocculent structures. Similar results were reported by Adin (1987) in a filter test experiment, which showed that very little removal occurred in the 1 to $2 \mu \mathrm{m}$ size range, while 10 to $60 \mu \mathrm{m}$ particles were reduced by $40 \%$ to $50 \%$ using "indepth filtration". Later research (Adin and Sacks, 1991) reported that particles ranging from $60 \mu \mathrm{m}$ to $300 \mu \mathrm{m}$ in size are a major factor in the clogging of emitters with gravel filters $(0.69 \mathrm{~mm})$ and disk filters $(120 \mathrm{mesh})$, but the particles in the sediment in this experiment would be much smaller than that. Filtration alone was not effective at preventing clogging. To improve the removal of biofilms, it might be useful to modify the emitter flow path structure or apply other physical or chemical treatments.

\section{Conclusions}

The conclusions derived from this study involving biomass accumulation and biofilm structure in drip irrigation emitter flow paths discharging reclaimed wastewater are as follows:

- PLFA and EPS analysis provided quantitative insight into the makeup of the microbial community within the emitter biofilm. The dominant microbial communities in the emitter flow path contained PLFAs 14:0, 16:0, 16:1w7c, 17:0, 18:2 $\omega$, and 18:0. The rapidly expanding biofilm accumulated cells and particles that induced a process that lead to emitter clogging.

- The trend of biomass accumulation in the emitter flow path fluctuates. The emitter path structure could affect the biofilm accumulation, and it is difficult to evaluate the clogging performance using only few structural factors.

- The biofilm initial adhesion occurred within the first 96 $\mathrm{h}$ of operation, and the biofilm played an inducing role in the clogging process.

- SEM analysis revealed the nature of the biofilm structure and development process. A flocculent structure was found in the matrix of the bacteriacoupling EPS that formed in the sediment within the emitter flow path. Microparticles that were not filtered were trapped by the biofilm and shaped the agglomerates. The filamentous bacteria and EPS played an important "bridging" function between the flocculent structures.

- The particle size of clogging sediment might be very small, and emitter clogging was not effectively controlled with a 140 mesh filter.

- Based on the results of this experiment, chlorine control might best be injected into the drip system between $48 \mathrm{~h}$ and $96 \mathrm{~h}$ to minimize biomass, since polysaccharides grow fastest during this period.

\section{ACKNOWLEDGEMENTS}

This work received support from the National Natural Science Foundation of China (Grant Nos. 50379053, 50609029, and 50779068), which is gratefully acknowledged.

\section{REFERENCES}

Adin, A. 1987. Clogging in irrigation systems reusing pond effluents and its prevention. Water Sci. Tech. 19(12): 323-331.

Adin, A., and M. Sacks. 1991. Dripper-clogging factors in wastewater irrigation. J. Irrig. Drain. Eng. 117(6): 813-825.

Ahimou, E., M. J. Semmens, G. Haugstad, and P. J. Novak. 2007. Effect of protein, polysaccharide, and oxygen concentration profiles on biofilm cohesiveness. Appl. Environ. Microb. 73(9): 2905-2910.

Cararo, D. C., T. A. Botrel, D. J. Hills, and H. L. Leverenz. 2006. Analysis of clogging in drip emitters during wastewater irrigation. Applied Eng. in Agric. 22(2): 251-257.

Characklis, G. W., and K. C. Marshall. 1990. Biofilms: A basis for an interdisciplinary approach. In Biofilms, 3-105. G. W. Characklis and K. C. Marshall, eds. New York, N.Y.: Wiley.

Costerton, J. W., Z. Lewandowski, D. E. Caldwell, D. R. Korber, and H. M. Lappinscott. 1995. Microbial biofilm. Ann. Rev. Microbiol. 49: 711-745.

Dehghanisanij, H., T. Yamamoto, B. O. Ahmad, H. Fujiyama, and K. Miyamoto. 2005. The effects of chlorine on emitter clogging induced by algae and protozoa and the performance of drip irrigation. Trans. ASAE 48(2): 519-527.

Donlan, R. M., and J. W. Costerton. 2002. Biofilms: Survival mechanisms of clinically relevant microorganisms. Clin. Microbiol. Rev. 15(2): 167-193.

Ford, H. W. 1979. Characteristics of slime and ochre in drainage and irrigation systems. Trans. ASAE 22(5): 1093-1096.

Frølund, B., R. Palmergen, K. Keiding, and P. H. Nielsen. 1996. Extraction of extracellular polymers from activated sludge using a cation exchange resin. Water Res. 30(8): 1749-1758.

Frostegard, A., A. Tunlid, and E. Baath. 1993. Phospholipid fatty acid composition, biomass, and activity of microbial communities from two soil types experimentally exposed to different heavy metals. Appl. Environ. Microbiol. 59(11): 3605-3617.

James, L. G. 1988. Principles of Farm Irrigation System Design. New York, N.Y.: Wiley.

Keinänen, M. M., P. J., Martikainen, and M. H. Kontro. 2004. Microbial community structure and biomass in developing drinking water biofilms. Canadian J. Microbiol. 50(3): 183-191.

Knoshaug, E. P., J. A. Ahlgren, and J. E. Trempy. 2000. Growth-associated exopolysaccharide expression in Lactococcus lactis subspecies cremoris Ropy352. J. Dairy Sci. 83(4): 633-640.

Kumar, C. G., and S. K. Anand. 1998. Significance of microbial biofilms in the food industry: A review. Intl. J. Food Microbiol. 42(1-2): 9-27. 
Leonardos, N., and I. Lucas. 2000. The nutritional value of algae grown under different culture conditions for Mytilus edulis $\mathrm{L}$. larvae. Aquaculture 182(3-4): 301-315.

Li, J., L. Chen, and Y. Li. 2009. Comparison of clogging in drip emitters during application of sewage effluent and groundwater. Trans. ASABE 52(4): 1203-1211.

McElhoe, B. A., and H. W. Hilton. 1974. Chemical treatment of drip irrigation water. In Proc. 2nd Intl. Drip Irrigation Congress, 215-220. St. Joseph, Mich.: ASAE.

Nakayama, F. R., and D. A. Bucks. 1991. Water quality in drip/trickle irrigation: A review. Irrig. Sci. 12(4): 187-192.

Oron, G., C. Campos, L. Gillerman, and M. Salgot. 1999. Wastewater treatment, renovation, and reuse for agricultural irrigation in small communities. Agric. Water Mgmt. 38(3): 223-234

Pennanen, T., J. Liski, E. Baath, V. V. Kitunen, J. Uotila, C. J. Westman, and H. Fritze. 1999. Structure of the microbial communities in coniferous forest soils in relation to site fertility and stand development stage. Microbiol. Ecol. 38(2): 168-179.

Pitts, D. J., D. Z. Hama, and A. G. Smajstra. 1990. Causes and prevention of emitter plugging in microirrigation systems. Bulletin 258. Gainesville, Fla.: University of Florida, Florida Cooperative Extension Service.

Ratcliff, A., M. D. Busse, and C. J. Shestak. 2006. Changes in microbial community structure following herbicide (glyphosate) additions to forest soils. Appl. Soil Ecol. 34(2-3): 114-124.

Ringelberg, D. B., S. Sutton, and D. C. White. 1997. Biomass, bioactivity, and biodiversity: Microbial ecology of the deep subsurface: Analysis of ester-linked phospholipids fatty acids. FEMS Microbiol Rev. 20(3-4): 371-377.

Rowan, M. 2004. The utility of drip irrigation for the distribution of on-site wastewater effluent. PhD diss. Columbus, Ohio: Ohio State University, Department of Food, Agricultural and Biological Engineering.
Şahin, Ü., Ő. Anapal 1, M. F. D őnmez, and F. Şahin. 2005. Biological treatment of clogged emitters in a drip irrigation system. J. Envrion. Mgmt. 76(4): 338-341.

Smith, C. A., C. B. Phiefer, S. J. Macnaughton, A. Peacock, R. S. Burkhalter, R. Kirkegaard, and D. C. White. 2000. Quantitative lipid biomarker detection of uncultivable microbes and chlorine exposure in water distribution system biofilms. Water Res. 34(10): 2683-2688.

Taylor, H. D., R. K. Bastos, H. W. Pearson, and D. D. Mara. 1995. Drip irrigation with waste stabilization pond effluents: Solving the problem of emitter fouling. Water Resour. 29(4): 1069-1078.

White, D. C., W. M. Davis, J. S. Nickels, and J. D. King. 1979. Determination of the sedimentary microbial biomass by extractable lipid phosphate. Oecologia 40(1): 51-62.

Xue, K., H. F. Luo, H. Y. Qi, and H. X. Zhang. 2005. Changes in soil microbial community structure associated with two types of genetically engineered plants analyzing by PLFA. J. Environ. Sci. China 17(1): 103-134.

Yan, D. Z., P. L. Yang, S. M. Ren, Y. K. Li, and T. W. Xu. 2007. Numerical study on flow property in dentate path of drip emitters. New Zealand J. Agric. Res. 50(5): 705-712.

Yan, D. Z., Z. H. Bai, M. Rowan, L. K. Gu, S. M. Ren, and P. L. Yang. 2009. Biofilm structure and its influence on clogging in drip irrigation emitters distributing reclaimed wastewater. $J$. Environ. Sci. China 21(6): 834-841.

Zhang, B. G., Z. H. Bai, D. Hoefel, L. Tang, Z. G. Yang, G. Q. Zhuang, J. Z. Yang, and H. X. Zhang. 2008. Assessing the impact of the biological control agent Bacillus thuringiensis on the indigenous microbial community within the pepper plant phyllosphere. FEMS Microbiol. Lett. 284(1): 102-108. 